\title{
Cozinha: espaço de relações sociais ${ }^{1}$
}

Marilu Albano da Silva ${ }^{2}$

Este artigo faz uma reflexão sobre a cozinha, não apenas lugar de preparo de alimentos, mas, principalmente, um espaço social, onde, e em torno do qual, homens e mulheres estabelecem relações cotidianas com os vizinhos, revelando redes de sociabilidade intracomunitária em um uso coletivo do espaço doméstico. Diante disso, indagamos: Como é constituído o conjunto de relações que acontecem em torno da cozinha? Qual a linguagem da cozinha e como ela se apresenta com seus símbolos e cultura material na experiência cotidiana das famílias? Nos espaços de preparação de alimentos em Mutamba da Caieira (RN), lugar onde foi desenvolvida a pesquisa, há momentos de intenso fazer doméstico entre a família e os vizinhos? Indagações que no decorrer deste procuramos afirmações privilegiando a cozinha, não só como um lugar de encontros (ou) de interação das técnicas das relações sociais e das representações dentro da família nuclear, no fazer doméstico, mas também uma cozinha que se estende pelo entorno (o terraço e o terreiro), uma cozinha externa mais social.

Para a Antropologia todo processo material é socializado e colocado em ação. Nas cozinhas tal processo acontece através das trocas de saberes, dos pequenos empréstimos de utensílios e produtos. Os favores na troca de um botijão de gás, os encontros para lavagem de roupas no terreiro de uma vizinha ou comadre, o compartilhamento de uma cozinha para o preparo de comidas ou até no cuidado do lar de uma vizinha quando esta precisa sair para ir ao médico ou a cidade. Tais representações refletem condições históricas e econômicas, como também valores sociais e culturais. As operações culinárias na cozinha são lugares de encontros (ou) de interação das técnicas das relações sociais e das representações.

Através da aquisição dos produtos alimentares, da preparação e distribuição do alimento entre as famílias da comunidade, a cozinha se impõe como espaço social por meio das condições que ele oferece para a produção dos alimentos, a circulação de objetos domésticos entre as famílias, a comunicação de saberes e o prazer de criação de receitas para expô-las à mesa, durante festividades e encontro com amigos. O trabalho

\footnotetext{
${ }^{1}$ Este artigo é parte de minha dissertação de mestrado defendida em setembro de 2008 PPGAS, UFRN sob a orientação da prof. Dr ${ }^{\mathrm{a}}$ Julie A. Cavignac.

${ }^{2}$ Universidade Federal do Rio Grande do Norte, Brasil.
} 
doméstico, principalmente o culinário, exige uma memória de gestos transmitidos pelos mais velhos, incorporados de tal forma pelas novas gerações, de modo que pelo aroma, consistência das comidas pode-se identificar o tempo de cozimento, temperatura necessária para cozinhar ou assar os alimentos, sem que seja preciso regras descritas em receitas (Giard, 2002; Elias, 1994).

\section{O espaço doméstico}

A casa não é apenas o abrigo familiar, mas também "o espaço de socialização e de sociabilidade; de religiosidade; de cuidado com a saúde; de reprodução alimentar” (Woortmann, 1991:16) que se constrói num processo englobante (Dumont, 1971) de pai, mãe, filhos e filhas. É nesse ambiente em que os primeiros sentimentos humanos como intimidade, cooperação, reprodução de habitus e costumes familiares são desenvolvidos, construídos e socializados. Bachelard (1978: 200), ao elucidar o conceito fenomenológico, expõe que "é preciso dizer então como habitamos nosso espaço vital de acordo com todas as dialéticas da vida, como nos em enraizamos, dia-adia, num canto do mundo”. Esse canto é a casa. Ela aconchega quando uma criança é repreendida pelos adultos e acolhe diante do medo. A mesma casa que protege também é o lugar das discórdias, dos conflitos familiares, é primeira noção de espaço social.

A casa é um micro-espaço do mundo, que em seu ambiente geográfico demarca comportamentos morais e normas sociais do grupo. Para Klaas Woortmann (1982), a casa constitui uma categoria central de um domínio cultural, ela é um mapa simbólico de representações ideológicas. Segundo ele para entender o significado de casa para um determinado grupo deve-se partir das próprias concepções desse grupo sobre seu significado, constatando, em estudos antropológicos e sociológicos, que:

\footnotetext{
A casa é sempre pensada pelo grupo em questão como a contrapartida material da família - e existência de uma família tem como requisito uma casa; correlatamente, a casa é o locus de realização do grupo domestico. No grupo por mim estudado em Salvador (Woortmann, 1975), a mesma palavra - casa - expressa tanto a idéia de uma estrutura material como de uma organização doméstica e outros estudos tanto em áreas urbanas (Heye, 1980) como rurais (Garcia Jr.,1975) revelam que essa estrutura material, o prédio, é, também, uma estrutura simbólica - um mapa, conforme dissemos - daquela organização. A casa é, então, a "materialização" da família, o espaço ritual onde seus membros interagem; é, também, o locus da produção da força de trabalho de seus membros individuais, na medida em que a família é uma estrutura de reprodução (Neto, 1978), e ainda, como coloca Macedo (1979), é no seu interior que as famílias constroem o seu mundo próprio e, através dele, se relacionam com o mundo externo (Woortmann, 1982: 120).
} 
$\mathrm{Na}$ casa os compartimentos revelam seus habitantes, expressam uma linguagem visual dos movimentos e cotidiano dos moradores. A cozinha é um lugar com expressão na casa.

Assim como Da Matta (1997: 27) no livro “A casa e a rua” propõe ao leitor indicar o caminho do quintal e da cozinha, proponho neste artigo, indicar o caminho da cozinha ao terreiro das casas em Mutamba da Caieira, com três lugares de cozinha, o fogo como um elemento essencial utilizado em diferentes fogões (a gás, a carvão e a lenha) e os demais utilitários domésticos mais usados nestes.

O fogo está sempre presente nas cozinhas no preparo das três refeições diárias, como diz um morador: "Se eu não comer um feijão no almoço ou um cuscuzinho com peixe assado no café de manhã e um torradinho de carne à noite é mesmo que não ter comido nada no dia” Regis Sobrinho de Macedo (2007).

O uso do fogão a lenha no terreiro denuncia uma sociabilidade construída numa base familiar que se amplia a toda comunidade através de operações simbólicas, rituais de técnicas, de favores e cooperação isso bem marcado quando na aquisição da lenha junto a mata. Algumas cozinhas possuem os três tipos de fogão - a gás, a carvão e a lenha - que se adequam ao estilo da vida familiar. Geralmente o fogão a gás é utilizado no interior da casa, o de carvão e o de lenha no terraço ou no terreiro. Os fogões a lenha dizem muito dos costumes alimentares de épocas passadas que não foram abandonados ou substituídos pelo fogão a gás, mas reelaborados e incrementados.

Observando o cotidiano das cozinhas da Mutamba da Caieira, podemos compreender o seu espaço com as suas singularidades no uso dos fogões a lenha, a carvão e a gás, essas cozinhas se comunicam entre si no modo de organização dos utensílios comuns, de criação dos animais domésticos, do cultivo das plantas comestíveis e nos saberes da preparação dos alimentos.

Seguiremos com a descrição dessas cozinhas utilizando um desenho para complementar o texto onde demarcarmos a cultura material, as relações sociais e simbólicas travadas no espaço da "cozinha dentro da casa”, da "cozinha do terraço” e da “cozinha do terreiro”, entendidos e conceituados em todo esse trabalho como lugar de cozinha na demarcação dos espaços na habitação. No desenho abaixo, mostramos os três tipos de cozinha e objetos que na maioria das casas são encontrados nesses espaços. Apesar de existir uma variedade de casas com os espaços citados, encontramos casas que não tem a cozinha do terraço. 


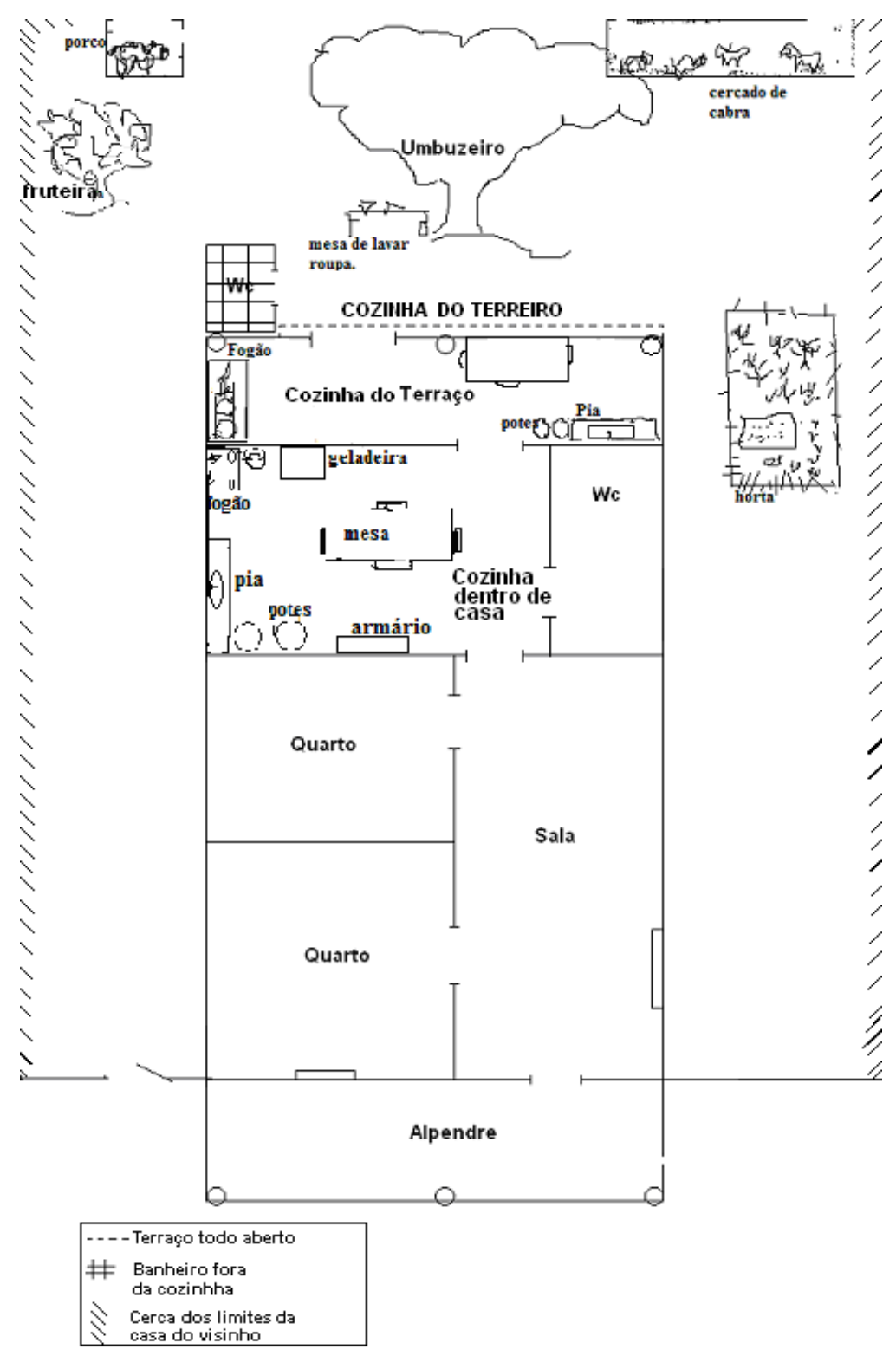

Croqui exemplo de uma casa com três cozinhas.

Em algumas unidades familiares verificamos que a cozinha interna é mais utilizada no turno da noite. Durante o dia só é usada se na casa não tiver nenhum tipo de fogão nos espaços externos. No entanto, se tiver um fogão no terraço, esse é apenas usado durante o dia. No item destinado a descrição do cozimento no terraço, desenvolveremos melhor esse assunto. As mulheres têm medo de trabalhar no terraço enquanto os filhos e o marido estão assistindo televisão ou conversando no alpendre. Na cozinha interna fica alojada a geladeira, o fogão a gás e os "alumínios” (recipientes e panelas) que são colocados numa bateria ${ }^{3}$, mesa das refeições com cadeiras, o guardalouça e reservatório para água. Algumas louças da diária ficam penduradas nas paredes,

\footnotetext{
${ }^{3}$ Bateria: grade de ferro retangular ou vertical com pequenos ganchos para pendurar panelas.
} 
dentro da uma bacia ou guardadas no armário. Algumas pessoas também guardam na cozinha objetos de trabalho como as redes de pesca e varas com anzol. Entre estes e outros objetos, na cozinha de dentro encontramos uma variedade de recipientes para guardar água, armazenar alimento e de outras utilidades, que são distribuídos nos espaços de acordo com sua funcionalidade.

Os utensílios empregados na cozinha são de materiais diversos como plástico, alumínio, cerâmica, madeira e vidro, usados para o preparo culinário. Os utensílios de diversas formas e texturas modelam, produzem estilos e padrões de organização dos espaços compartilhados pelos moradores, de acordo com o poder aquisitivo das famílias. As de poder aquisitivo mais elevado desfrutam do uso dos utensílios de cozinha modernos, como batedeira de bolo elétrica, fogão a gás (acionado a energia elétrica), armários de aço nas paredes, freezer, geladeiras, bebedouro elétrico, dentre outros. As famílias que não podem comprar esses utensílios usam da criatividade na elaboração de objetos conforme a necessidade de uso.

A cozinha interna, em certas ocasiões serve também para marcar uma posição social; é o lugar onde as visitas são recebidas; sejam da cidade que não freqüenta assiduamente a comunidade, um compadre ou comadre, uma pessoa importante ou alguém da família que mora na capital ou em outro lugar. Dona Chiquinha enfatiza o cuidado com as visitas importantes:

\begin{abstract}
A gente usa mais a cozinha dentro de casa às vezes nos domingos ou quando chega uma visita, seja uma pessoa importante da família, uma amiga que mora fora que a gente não vê há muito tempo, uma comadre. Aí, eu coloco a toalha nova na mesa e os pratos melhorzinhos, que não é usado no dia-a-dia, aí sirvo o almoço ou o jantar com que tivermos para dar e mostrar para aquela pessoa que chega na nossa casa.
\end{abstract}

A cozinha interna é preferida à noite para prevenção do mal indesejado: "eu tenho medo do malfazejo ${ }^{4}$, a gente come dentro da cozinha à noite quando fica tudo escuro".

As paredes baixas permitem pendurar os utensílios mais utilizados. Objetos estão distribuídos por todos os espaços da cozinha; a mesa no centro, que se projeta para as refeições diárias, também é lugar para colocar utensílios depois de lavados.

A higiene dos objetos é feita pelas mulheres e crianças do sexo feminino. As crianças lavam os itens mais leves, compatíveis com sua força e coordenação motora; os

\footnotetext{
${ }^{4}$ Dona Chiquinha diz que malfazejo é pessoa má que pode aparecer à noite quando mais tarde e está escuro ela pode fazer o mau a quem está fora, no terraço ou terreiro da casa.
} 
adultos, a mãe ou avó, ficam responsáveis pelos objetos mais pesados. Os recipientes de água e as panelas de barro são limpos pelas mulheres mais experientes que também são responsáveis pelo brilho nos objetos de alumínio. Arear os objetos de alumínio com lã de aço ou areia fina é uma atividade importante na cozinha, pois estão diretamente relacionados a higiene pessoal.

Os objetos são expostos na cozinha em prateleiras (objetos feitos com aço em formato vertical ou horizontal,) compradas nos armazéns da cidade do Assu (RN). A prateleira é um dos objetos mais usados nas cozinhas das casas da zona rural, seja elas de alvenaria ou de taipa, para guardar utensílios de alumínios como cuscuzeiras, assadeiras de bolo em diferentes formatos, caçarolas, frigideiras, chaleira, bule ${ }^{5}$ e panelas que ficam em lugar de destaque, onde possam ser apreciados pelos visitantes. No que se refere a exposição dos utensílios percebe-se também ser esta uma forma de mostrar o nível social, pois nas casas de taipa ou as que não tem fogão a gás, principalmente, a quantidade e variedade dos utensílios de alumínio é menor.

\section{A organização dos utensílios}

Os recipientes de cerâmica armazenam a água destinada ao cozimento dos alimentos e o recipiente de plástico guarda a água de beber. Os recipientes de plástico são depósitos grandes de margarina utilizados como filtro; dispõem um em cima do outro fazendo uma pequena incisão na parte de baixo e colocam uma torneira de plástico comprada nos estabelecimentos comerciais da cidade de Assu. A cerâmica é adquirida na feira livre ou em armazéns da cidade.

Os copos em cima das tampas dos depósitos de água são de uso coletivo. É um hábito de algumas famílias que moravam nos sítios, onde mais de uma pessoa usa o mesmo copo para beber água; o copo de asa ou caneca plástica é utilizado para pegar água do recipiente, colocar em outro copo para consumo. O copo é usado de forma coletiva desde que os membros das famílias saíam para plantar ou colher nos roçados longe de suas casas levando água num recipiente de cerâmica ou cabaça utilizando uma caneca de uso comum.

Em algumas casas esse costume foi substituído pelo o uso do copo individual, pendurados nas paredes ou arrumados em uma badeja em cima da boca do pote

\footnotetext{
${ }^{5}$ Bule recipiente para colocar o café, hoje em muitas residências foi substituído pela garrafa térmica.
} 
A mesa é usada para o preparo de alimentos, desde a escolha de sementes ao corte de carnes e legumes. Também é utilizada durante os intervalos das refeições para colocar louças limpas para secar em bacias e para engomar a roupa.

Na maioria das cozinhas os armários de madeira, confeccionados por pequenas marcenarias na cidade; são adquiridos para guardar a louça que é usada nos finais de semana ou para receber uma visita de outra localidade e com menos intimidade com a casa; também é usado para guardar pequenos depósitos de plásticos ou alumínio. Outros armários são improvisados como os de caixotes de madeira que ficam pendurados na parede para colocar pequenos recipientes com temperos secos.

O fogão a lenha possui uma bancada grande onde são colocados utensílios para preparo das comidas, panelas quentes, tábuas de carne e preparo dos pratos das crianças que às vezes comem sentadas no chão da cozinha.

As cozinhas de taipa são ambientes baixos e de paredes escuras. As mulheres usam lamparina para fazer o fogo ou auxiliar na procura de objetos nas partes internas dos fogões que são escuras. A lamparina é um objeto muito útil a cozinha e fica sempre ao alcance fácil, geralmente em um jirau perto do fogão, na parte de cima, pois a utilização de fósforo para atear fogo é um grande desperdício, tendo em vista a dificuldade de acender a madeira. Os objetos que são utilizados diretamente na cozinha relacionados a alimentação da família encontram-se nos lugares apropriados à sua utilização.

\title{
A cozinha do terraço: lugar de homens e de mulheres.
}

\begin{abstract}
A cozinha [de dentro de casa] é das mulheres, o homem tem que respeitar que a mulher quando está na cozinha ela está mexendo em comida, coisa dela; homem não deve estar no meio das mulheres na cozinha. Se elas estão trabalhando pra que o homem entrançando no meio da cozinha? Quando é mulher de outra casa que entra tudo bem. O homem só deve entrar na cozinha quando a comida está pronta e ela chamar. O trabalho de comida é só de mulher. (Sr. Eduardo, 84 anos, antigo morador da Mutamba, 2007).
\end{abstract}

Seu Eduardo demarca o espaço da cozinha dentro de casa e a posição masculina nesse espaço, lugar onde o homem só deve entrar para fazer as refeições. Observa-se nesse comentário que o espaço doméstico da mulher no que diz respeito ao culinário e sua posição de poder (Dumont, 1971) na cozinha estão relacionados ao alimento cozido. O espaço do culinário masculino é aquele do abate do animal e a preparação das carnes para o alimento. 
Seu Eduardo comenta ainda sobre o motivo pelo qual a cozinha de dentro de casa não é muito usada pelas mulheres durante o dia, mas a do terraço e a do terreiro, pois no cotidiano as redes de sociabilidades são mais restritas aos grupos familiares (primos, parentes mais distantes) e vizinhos. Esse é um momento em que as mulheres, em meio as suas tarefas diárias, tomam parte dos acontecimentos na comunidade. Ficam sabendo como estão os preparativos de uma festa, quando alguém vai à cidade, quando nasce uma criança, quando um bem é adquirido, enfim de todos os acontecimentos sociais:

As mulheres colocaram o fogo aqui fora porque gostam de cozinhar em lugar aberto olhando as pessoas passarem na estrada e quando não estão fazendo comida, elas estão sempre conversando aqui no terraço com quem chega umas com as outras pelos quintais.

É no terraço onde geralmente são executadas tarefas coletivas entre homens, mulheres e crianças, seja da família ou vizinhos. São tarefas que requerem um número maior de pessoas, principalmente quando se trata de matar o animal para realização de festas ou em épocas de abundância de alimentos da roça ou da pescaria. Neste inciso apontaremos alguns terraços com fogões, homens e mulheres executando tarefas, momento de socialização e de muita conversa.

Dependendo do horário o terraço fica repleto de pessoas; se for uma casa com a frente para o poente o terraço passa a ter a função de alpendre nas tardes quentes, porque fica arejado e é onde acontece o encontro familiar e de vizinhos que aproveitam para conversarem e tomar café nos intervalos do trabalho

\section{O terraço de Dona Chiquinha}

É aqui no terraço onde é feito a comida do dia-a-dia. Entra todo mundo, qualquer homem conhecido da vizinhança pode chegar pelos lados da casa e se sentar nesse terraço enquanto nós mulheres estamos conversando e lavando louças, cozinhando, continuamos fazendo qualquer coisa, qualquer trabalho sem nenhuma cerimônia. Estar perto dos homens não atrapalha nossas tarefas só se eles vierem dar pitaco. Dona Chiquinha.

Palavra de uso popular pitaco significa dar opinião, interferir na forma de realizar as atividades na cozinha. A cozinha do terraço é um lugar de homens e mulheres. Os homens não interferem no fazer culinário e obedecem as regras impostas pelas mulheres de comportamento nesse espaço. O terraço é uma cozinha aberta e arejada, uma cozinha de parentes, de uma família mais ampla, de amigos, ou seja, uma cozinha mais social. Na maioria das casas é na cozinha do terraço que os fogões a 
carvão são colocados, alguns improvisados com latas de querosene velhas ou pelo reaproveitamento do fogão a gás envelhecido. A criatividade no reaproveitamento e reutilização dos objetos, criando utilitários é extraordinária nas cozinhas rurais de Mutamba da Caieira.

As mulheres também cozinham a lenha no terraço e os trabalhos se estendem até o anoitecer durando até a última refeição. No entanto a higienização dos utensílios usados no jantar é feita somente no dia seguinte pela manhã, pois acreditam nas histórias das almas, contadas pelos antepassados:

\begin{abstract}
Os mais velhos, já no tempo de nossas tataravôs e avós, diziam que não se deve lavar a louça da janta; bem, naquele tempo se chamava ceia, porque as almas, quando a gente está dormindo elas vêem na nossa cozinha e se agente deixou tudo limpo está agourando que alguém da nossa família morra de fome. Dizem que é pra deixar a louça suja para quando a gente dormir aquelas almas que morreram de fome vim comer os restos de comida que ficaram nos pratos. Eu mesma nunca lavo a louça de noite. (Maria Elenir de Castro, 22 anos, 2008).
\end{abstract}

Lavar a louça do jantar no outro dia por causa das almas é uma justificativa recorrente pelas mulheres de várias cozinhas. Dona Maria Sales afirmou que quando está com disposição lava a louça à noite, "mas sempre deixo minha cuscuzeira cheia de comida em cima do fogão para as almas se a caso elas vierem na minha cozinha procurar comida”. No que diz respeito às recorrências, conjugo com Julie Cavignac quando expõe que “o sobrenatural está, portanto presente em todo os momentos da vida do sertanejo e se integra a uma representação de mundo necessariamente harmônico (...)” (2006:241).

\title{
Trabalho e conversa no terraço.
}

É comum na comunidade presenciar pessoas preparando comidas no terraço. $\mathrm{O}$ trabalho coletivo no espaço do terraço algumas vezes são executadas por mulheres e homens na jornada diária com vizinhos ou parentes é uma forma de apreender com o outro um fazer culinário repleto de significações simbólicas transmitidas e absorvidas por todo grupo doméstico.

O modo de tratar um peixe, matar um peba ${ }^{6}$, preparar uma perna de bode, fazer uma buchada são apreendidos no cotidiano doméstico que socializam as relações comunitárias pelo espaço da cozinha. Por exemplo, uma jovem não faz cerimônia ao

\footnotetext{
${ }^{6}$ Peba é tatu.
} 
chamar uma idosa para tratar um peixe ou uma galinha em sua casa mesmo que saiba fazer isso sozinha, pois juntas compartilham o alimento e socializam o tempo. Uma jovem que tratava um peixe com uma vizinha de 70 anos, conta: “Chamei ela para tratar esses peixes comigo porque a gente fica conversando, aí o tempo passa logo, e não cansa muito”, se referindo ao tédio da tarefa doméstica que é repetitiva e solitária.

Diante dos relatos e das observações preliminares realizadas em cozinhas na comunidade da Mutamba da Caieira registrei algumas peculiaridades como o modo de matar e preparar o animal, diferente do executado nas cozinhas urbanas. Nesta o animal já chega morto e, por muitas vezes, temperado, para o manuseio solitário de uma dona de casa, de uma empregada doméstica ou outra pessoa responsável pela tarefa.

Enquanto Dona Chiquinha e a nora Elenir faziam canjica, no outro lado do terraço seu marido conversava com uma visita que experimentava o prato feito pelas duas. Elas se revezavam entre mexer a canjica e colocar carvão no fogo. Aproveitei para conversar com o senhor Eduardo que estava sentado na meia parede do terraço olhando as duas trabalhar enquanto fumava um cigarro de fumo grosso que ele mesmo tinha feito; jogava a fumaça por todo o terraço respondendo às minhas perguntas na mais invejável paciência. Disse que não ajudava as mulheres na comida de milho porque a tarefa dele já havia feito no roçado; plantou, cuidou da plantação, colheu e trouxe até em casa as espigas.

A neta de senhor Eduardo, sentada observava todo o movimento na cozinha. As crianças aprendem olhando os adultos executarem os afazeres e ajudando nos pequenos trabalhos domésticos. É observando continuamente que incorporam a tradição de costumes e fazeres que realizarão também quando adultos.

A cozinha do terraço da casa de Dona Chiquinha que possui uma família extensa e compartilha as tarefas com sua nora. Todos os dias Elenir, que é vizinha de Dona Chiquinha, realiza suas atividades domésticas na casa da sogra onde comem as duas famílias. A casa dos pais fica no centro e a dos filhos dos lados. A esposa do outro filho também compartilha as tarefas, contudo faz as refeições em sua própria casa. Dona Chiquinha afirma que é “uma mulher sem aperreios na cozinha, é uma mãe para todos”. Quando precisa sair de casa para resolver alguma coisa na cidade é para sua nora, Elenir, que repassa as tarefas. "Ela toma conta da casa, ela faz comida para todos do mesmo jeito que eu faço e todos que estão em casa respeita as atitudes dela na minha falta”. O trabalho de cozinha para Dona Chiquinha é sem fim, uma rotina que só 
termina quando vai se deitar. No seu relato mostrar uma longa jornada diária de trabalho na cozinha:

Aqui eu acordo com os passarinhos. Logo cedo faço a comida para os que vão trabalhar, depois tomo um cafezinho e vou cuidar dos bichos, dar comidas para as galinhas, para os porcos. Fico sempre fazendo o que precisa fazer, lavo umas coisinhas, vou preparar o almoço; quando terminam de almoçar às vezes dou um cochilinho, às vezes não, aí fico fazendo alguma coisa na cozinha; quando chega por volta das quatro horas começa o rebuliço de novo na cozinha; eu e ela começamos a preparar a janta para todo mundo, depois, lá pra noves horas, é que vou me deitar. Quando tem uma pessoa doente aqui em casa, sou eu quem acordo e vou fazer um chá, quando alguém vai decidir alguma comida aqui na cozinha, sou eu quem vejo o que é melhor, pergunta logo pra minha permissão.

As mulheres falam de sua rotina doméstica como um trabalho de jornada longa, com divisões de tarefas e tempo determinado, na sua maioria direcionado para a alimentação, desde a higienização dos utensílios ao preparo e o consumo dos alimentos pela família. Ela comunga com um universo de mulheres da comunidade que acordam muito cedo, no clarear do dia para trabalhar.

Algumas mulheres já trabalharam fora nas lavouras de sítios vizinhos apanhando feijão, plantando hortaliça e limpando mato que nascem entre a plantação. Hoje, são poucas as que fazem esse trabalho. A maioria das mulheres trabalha em suas residências, nas tarefas domesticas. Dona Maria Vitorino, mais conhecida como Dona Mocinha, em tom lamurioso narra sua árdua tarefa domestica diária:

É duro o trabalho doméstico. Estou tão cansada hoje. Acordo às vezes ainda escuro que não abro a porta para fazer o fogo de lenha aqui no terraço e fico na cozinha preparando a massa do cuscuz, lavando uma louça, esperando o dia clarear para fazer o fogo e preparar a comida pra os que vão trabalhar na firma. Faço a marmita, eles levam. Depois de fazer a comida para eles levarem é que vou tomar café, depois vou dar de comer aos bichos, vou lavar a louça do café ou a que ficou da janta de ontem à noite, aí vou varrer, lavar roupa, fazer almoço; depois do almoço vem tudo de novo. Descanso quando posso um pouquinho depois do almoço, mas não é todo dia; quando chega de noite estou morta de cansada, É, trabalho de casa é muito duro!

A jornada doméstica executada nas cozinhas da comunidade começa cedo para as mulheres responsáveis pela alimentação diária da família. Dona Maria Fernandes da Silva não tem filho que trabalha nas firmas, mas ao raiar do dia:

Sou aposentada, minha casa vive cheia de gente. Eu acordo com os passarinhos e começo cedo a trabalhar; gosto de fazer o fogo; cedinho retiro as cinzas do fogão, quando o fogo está aceso, faço o café, cuscuz, frito um peixe que é bom de manhã com cuscuz, eu gosto. Feijão só faço no fogo a lenha, gasta muito gás. Quando não tem lenha vou ali na mata e trago um 
feixe de lenha ${ }^{7}$. Tem um menino aqui que me ajuda, mas se ele não poder ir eu mesmo vou. Eu cozinho mais o feijão porque é uma comida mais pesada, demora mais no fogo, gasta muito gás. Eu economizo muito cozinhando no fogo a lenha. Trabalho desde criança, minhas filhas, a Maria José, só come uma galinha feita por mim. Ave Maria! Trabalho muito na cozinha, eu crio muitos bichos, peru, galinha, pato e eles dão muito trabalho. (Relato de abril de 2007. Faleceu em fevereiro de 2008.

As mulheres, independentemente da idade ou o estado civil, demonstram através de seus relatos a compreensão de que as tarefas domésticas na cozinha é um trabalho duro e de grande responsabilidade, principalmente para a dona da casa. O tempo de desenvolvimento de cada serviço é planejado de acordo com a necessidade de alimentação do homem que trabalha fora e das crianças que vão para a escola. Há uma seqüência de ocupações determinadas no cotidiano na cozinha que são repetidas diariamente, cumprindo rigorosamente o mesmo horário. Mesmo as mulheres que consideram as tarefas domésticas como uma "luta sem fim" não reivindicam o compartilhamento por parte dos homens nesses afazeres; nesse aspecto a questão de gênero é bem definida. Cabe ao homem o trabalho fora de casa, no roçado, nas firmas, nos sítios vizinhos. O trabalho do masculino no espaço da cozinha está diretamente ligado aos cuidados dos animais que ficam no terreiro, em pequenos cercados. A ocupação com os animais que ficam no entorno da casa, na área do quintal, é incluída nas obrigações domésticas diretamente ligadas a cozinha, cabendo a mulheres e crianças a responsabilidade de alimentá-los colocando restos de comidas e sobras das cozinhas da comunidade.

Enquanto o homem se responsabiliza pela manutenção dos alimentos para a família, procurando-os fora de casa, a mulher se encarrega de manter a ordem dos trabalhos na casa distribuindo tarefas para filhas e filhos que ficam aos seus cuidados, transmitindo saberes e mantendo a autoridade "moral” do lar, que nesse aspecto é um espaço feminino.

Dona Chiquinha fala de trabalho com autoridade de quem é dona de um espaço e de uma qualificação que adquiriu durante longo aprendizado no seio da família. Ela determina no cotidiano da cozinha o cardápio de todas as refeições. Autoridade nos saberes relacionados à saúde da família, na horta doméstica cultiva plantas usadas no preparo de chás e lambedores usados quando alguém fica doente. Nesse sentido, ela tem o poder sobre filhos e netos afirmando o ciclo “englobante” (Dumont, 1971) numa

\footnotetext{
${ }^{7}$ Feixe de lenha: certa quantidade de lenha.
} 
relação da ordem pai, mãe e filho (a). Na constituição familiar. Referindo ao marido ela diz:

ele é o dono da casa e de mim e de toda família. Me casei com ele fugida; tinha 14 anos quando comecei a namorar, então convidei ele para casar e ele aceitou; ele me carregou e botou na casa de um primo dele; depois meu pai foi no roçado e falou com ele qual as intenção dele e ele disse que era casar; então fui morar com ele, desde daí sou dele.

O relato acima configura o que autores como Dumont (1971) compreendem como poder englobante na ordem pai, mãe e filho que é construído nas esferas sociais e simbólicas da sociedade. O homem como chefe da família nuclear se posiciona em uma ordem englobante, onde determinação de ordem externa como a proteção do lar está diretamente ligada a ele. No depoimento acima, a senhora expressa sentir-se englobada pelo poder do homem com relação ao ambiente doméstico numa divisão de poderes sobre esses espaços. A cozinha, no ponto de vista masculino, é o espaço da casa estritamente controlado pela mulher. Durante a pesquisa, ao pedir permissão para realizar a observação muitas das senhoras olhavam imediatamente para o esposo num gesto de que a ele cabia a decisão. Entretanto, quando informava minha área de interesse, imediatamente a responsabilidade era transferida para a esposa; a cozinha era um espaço dela, espaços que são delimitados pelo gênero. Heredia (1979:95) esclarece esse fato quando diz que "embora toda a casa seja um espaço feminino, dentro dela, (...) existem espaços mais masculinos ou mais femininos que outros. A cozinha é o espaço feminino por excelência, assim como a sala é o mais masculino dentro da casa”.

\section{A terreiro.cozinha do terreiro.}

O terreiro é concebido como uma extensão da cozinha. Apontado nos estudos de Heredia (1979) é um lugar que fica na parte posterior da habitação dando acesso a cozinha por onde não entram pessoas estranhas, somente parentes ou alguns vizinhos de grande amizade e confiança da família.

Entretanto, este estudo mostra que a parte posterior da casa, o espaço do terreiro das casas da Mutamba da Caieira é um espaço onde se desenvolvem relações de sociabilidade intracomunitárias, onde em algumas casas fica o fogão a lenha, este pode ser construído embaixo de uma árvore ou protegido por um pequeno cercado de madeira coberto com telhas, ou palhas de coqueiro. Em algumas culturas a cozinha é 
desmembrada da estrutura física da moradia, como a cozinha árabe que comumente fica ao ar livre (Rosenberger, 1998).

Faremos uma leitura desse espaço, baseados na concepção de cozinha para Poulain (2006:256) de que “é um espaço no sentido lógico do termo, de relações estruturais”, portanto uma cozinha mais social. Explicaremos como esse espaço se apresenta nos eventos relacionados a alimentação que costumeiramente acontecem na comunidade como a rifa do Pacará, que eu descrevo em um capitulo da dissertação denominado, A festa do Pacará, onde vejo como um momento singular que acontece na comunidade.

Na Mutamba da Caieira a cozinha ao ar livre é usada pela família extensa; os filhos que moram ao lado da casa dos pais dividem o mesmo espaço do terreiro. $\mathrm{O}$ fogão fica afastado das instalações da habitação como uma estratégia de afastar a fumaça das paredes para não escurecê-las e de permitir o uso comum pelas famílias. No entanto, o vento gasta mais rápido a lenha e desperdiça calor; mesmo assim é uma maneira de ganhar tempo nas tarefas, pois, enquanto cozinham nesse espaço, as mulheres executam vários trabalhos, como alimentar os animais, lavar roupa, varrer, cuidar do canteiro de hortaliça. Satisfazem-se em trocar idéias e conversar pelo entorno da casa com os vizinhos. Muitas atividades são executadas embaixo do imbuzeiro, árvore que tem várias utilidades na vida diária dos moradores da Mutamba da Caieira como a renda obtida no período de safra, pois arrendam toda a produção ainda com a fruta verde no pé para um mangaeiro ${ }^{8}$. Os pés de imbuzeiro são utilizados também como poleiro de galinha, para colocar utensílios do trabalho diário, como cangalhas ${ }^{9}$ de jumento, enxada, objetos que não estejam mais sendo usados no roçado. Por armazenar grande quantidade de água nas raízes, a copa do imbuzeiro forma uma enorme sombra distribuída em boa parte do quintal durante certo período do ano.

São embaixo dos imbuzeiros onde se concentram grande parte do trabalho da cozinha dessa comunidade rural desenvolvida por homens, mulheres e crianças,como alavagem de roupa pelas mulheres.

Certo dia cheguei cedo à casa de Maria Auxiliadora de Lemos. Ela estava com outra senhora, Aldeize, lavando roupa no terreiro da casa, embaixo de um pé de umbu; o lavadouro era uma tábua suspensa por varas formando uma bancada coberta com um plástico para que as roupas não tivessem contato com a madeira. Nesse lugar do terreiro

\footnotetext{
${ }^{8}$ Mangaeiro: pessoas da região que compram frutas dos sítios para vender no mercado de atacado das capitais.

${ }^{9}$ Cangalhas: sela utilizada no jumento.
} 
também está o chiqueiro dos porcos, que se banham com a água derramada da lavagem de roupa. A água usada para lavar a roupa é armazenada em um tanque grande. Segundo elas o processo de lavagem é cansativo, pois retiram água de um reservatório com um balde de plástico cortado na parte de cima onde é colocado um pedaço de madeira em substituição a alça para conduzir uma quantidade de água do tanque e adicionar nas bacias. Molham várias roupas ao mesmo tempo arrumando as peças empilhadas uma em cima das outras; assim, na medida em que passam sabão, a água se infiltra nas roupas como um todo. Depois de ensaboada, a roupa é colocada no quarador ${ }^{10}$ e estendida, ainda molhada com sabão, em cima de pedras para levar sol por um tempo, depois retirada e enxaguada, removendo a sujeira por completo; depois, é estendida no varal ou nas pontas das varas do quintal.

\begin{abstract}
Hoje todas pessoas dessa comunidade lavam roupa em casa. Antes não tinha água encanada na comunidade. Nós pegávamos um 'carro de linha ${ }^{11}$ e parávamos em uma entrada que, caminhando uns três quilômetros ia dar no Rio Assu e lá agente ficava a manhã toda; só voltava a tarde com as roupas limpas e enxutas; comia lá mesmo, levava de casa a comida; voltava a pé, andava muito; íamos uma vez por semana, quando juntava muita roupa e mais de duas mulheres para ir juntas (Doura, 26 anos, maio de 2007).
\end{abstract}

As mulheres improvisam as lavanderias embaixo dos imbuzeiros programam os dias das lavagens, e assim executar essa atividades compartilhando saberes e conversas do cotidiano.

A rotina da cozinha é agregada à dinâmica das atividades diárias da casa e da comunidade. É um espaço que compreende um “conjunto de movimento produzido pelas operações que o orientam, o circunstanciam, o temporalizam e o levam a funcionar em unidade” (Certeau, 2002: 221).

Na cozinha, dentro da casa, do terraço e do terreiro, passos e gestos são repetidos em incontáveis vezes para execução rotineiras das tarefas diárias: olhar a comida no fogo, experimentar seu sabor, verificar a sua consistência, cozinhar, depois servir e comer, levantar continuamente para lavar a louça, tirar os pratos da mesa lavá-los, enxugá-los, guardá-los, reiniciando, ordenadamente, as mesmas ações para o preparo da próxima refeição. Essas infinitas práticas que envolvem a culinária demandam um saber guardado na memória, como explica Giard (1996: 220, grifo da autora): “As mulheres

\footnotetext{
${ }^{10}$ Quarador: local usado para expor a roupa ao sol para alvejar.

${ }^{11}$ Carro de linha: ônibus de empresa de transporte rodoviário.
} 
manejam utensílios e ingredientes, colocando para funcionar uma "inteligência” sutil, cambiante e de descobertas iminentes [...] em fim, uma "inteligência bem comum”.

\section{Referências,}

CERTEAU, Michel, de. A invenção do cotidiano v.1, arte de fazer, Petrópolis - RJ. Vozes, 2002.

DUMONT, Louis. Intruducotin à deux théores d'anthropologie sociale. Paris, Mouton. 1971.

ELIAS, Nobert. O processo civilizador, Uma história dos costumes. Rio de Janeiro, Jorge Zahar, 1990.

GIARD, Luce. Cozinhar. In, CERTEAU, Michel de; GIARD, Luce; MAYOL, Pierre. A Invenção do Cotidiano 2, morar, cozinhar. 4. ed. Petrópolis, Vozes, 2002.

HEREDIA, Beatriz M. Alásia. A Morada da Vida, trabalho familiar de pequenos Produtores do nordeste do Brasil. Rio de Janeiro, Ed.Paz e Terra, 1979.

MATTA, Roberto da. A casa \& a rua. Rio de Janeiro, Rocco, 1997.

ROSENBERGER, Bernard. A cozinha árabe e sua contribuição à cozinha européia. FLANDRIN, Jean-Louis; MONTANARI, Massimo (Orgs.). História da Alimentação. 3. ed. Tradução de Luciano Vieira Machado e Guilherme J. F. Teixeira. São Paulo, Estação Liberdade Ltda., 1998.

POULAIN, Jean-Pierre. Sociologia da alimentação, os comedores e o espaço alimentar. Florianópolis, Ed. Da UFSC, 2004.

WOORTMANN. Ellen. F. Da complementaridade à Dependência, a mulher e o ambiente em comunidades "pesqueiras” do nordeste. Brasília. Série Antropológica. 1991.

WOORTMANN. Klaas, Hábitos e ideologias alimentares em grupos sociais de baixa renda, Relatório final. Brasília Série antropológica. 1978. 